\title{
BRITTLENESS OF Mg ADDED Bi OXIDE
}

\author{
Mg 添加した Bi 系酸化物超伝導体の脆性
}

Kiyotaka Mori, Kaoru Usui, Nobutake Hirai, Yuichi Kawaguchi,

Hiroko Yamamoto, Kazuya Oguri and Yoshitake Nishi

Department of Materials Science, Tokai University, 1117 Kitakaname,

Hiratsuka, Kanagawa, 259-12 Japan.

( Accepted for publication 17 November 1994 )

\section{1 目的}

Bi 系酸化物超伝導体は $100 \mathrm{~K}$ 以上の超伝導遷移 温度 $\left(\mathrm{T}_{\mathrm{c}}\right)$ を示し、将来実用化へ向けて有望であ る。しかしこの酸化物は非常に脆く加工性が悪い ことが問題となっている。

そこで、本研究では Mg 添加した Bi 系酸化物 超伝導体を液体急冷法を用いてアモルファス化し 脆性評価を行った。

\section{2 実験方法}

試料の基本出発組成は $\mathrm{Bi}_{1.6} \mathrm{~Pb}_{0 .} \mathrm{S}_{2} \mathrm{Sr}_{2} \mathrm{Ca}_{2} \mathrm{Cu}_{3} \mathrm{O}_{\mathrm{x}}$ 之 し、原料には $\mathrm{Bi}_{2} \mathrm{O}_{3}, \mathrm{PbO}, \mathrm{SrCO}_{3}, \mathrm{CaCO}_{3}, \mathrm{CuO}$ 及 び添加元素として Mg0 の高純度粉末を使用した。 原料粉末を秤量・混練・圧粉し、大気中 $1023 \mathrm{~K}$ で $6 \mathrm{~h}$ の仮焼結後空冷し、大気中 $1023 \mathrm{~K}$ で $18 \mathrm{~h}$ の仮焼結後空冷した。その後、大気中 $1123 \mathrm{~K}$ で $12 \mathrm{~h}$ の本焼結後空冷し焼結体を 作製した。焼結体をFigure 1 に示す 双ピストン・アンビル型急冷凝固装置を用いて 液体急冷法によりアモルファス試料を作製した。 ${ }^{2}$

脆性の評価には、島津製作所製超微小硬度計 （ DUH-50）を用いた。この装置は加える荷重を 連続的に変化させ、荷重之圧子の押し込み深さの 関係を求める装置である。Figure 2 に、この 装置より得られた $L_{g}-h_{g}$ 曲線の模式図を示す。 なお、実験時の最大荷重は $50 \mathrm{gf}$ であり 毎秒 $0.13 \mathrm{gf} / \mathrm{s}$ で $0 \mathrm{gf}$ から増やしていった。 測定回数は 1 つの試料につき 5 回行った。測定に 使用した圧子の対棱角度は $100^{\circ}$ であった。
破壊が起こると応力が緩和され変曲点が現れる。 すなわち、この変曲点の現われたときに マイクロクラックが発生する。なお、この マイクロクラックが発生したときの時の荷重を $\left(\mathrm{L}_{\mathrm{g}}\right)$ 、圧子の押し込み深さを $\left(\mathrm{h}_{\mathrm{g}}\right)$ とした。 ところで、 $\mathrm{L}_{\mathrm{g}}, \mathrm{h}_{\mathrm{g}}$ だけでは、硬さの異なる材料の 評価は正しくできないのでマイクロクラックの形 成に必要な変形エネルギー $\left(\mathbb{W}_{\mathrm{g}}\right)$ 值で評価を 行った。男は（1）式より求めることができる。

$$
\mathrm{W}_{\mathrm{g}}=\mathrm{L}_{\mathrm{g}} \times \mathrm{h}_{\mathrm{g}} / 3
$$

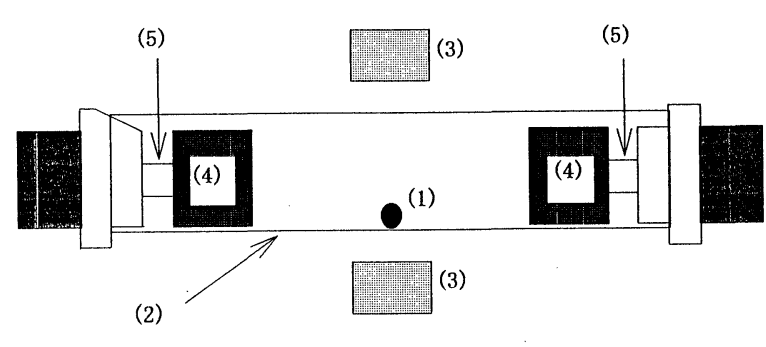
(1) Specimen
(4) Cu substrate
(2) Quartz tube
(5) Air piston
(3) Infrared furnace

Figure 1. Twin-type piston anvil apparatus 


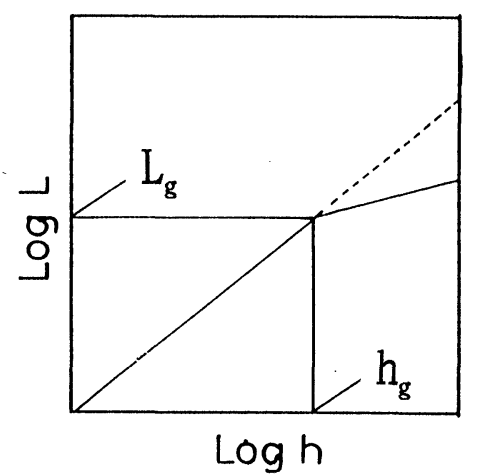

Figure 2. Load ( L ) vs ultra micro-Vickers indentation depth $(\mathrm{h})$

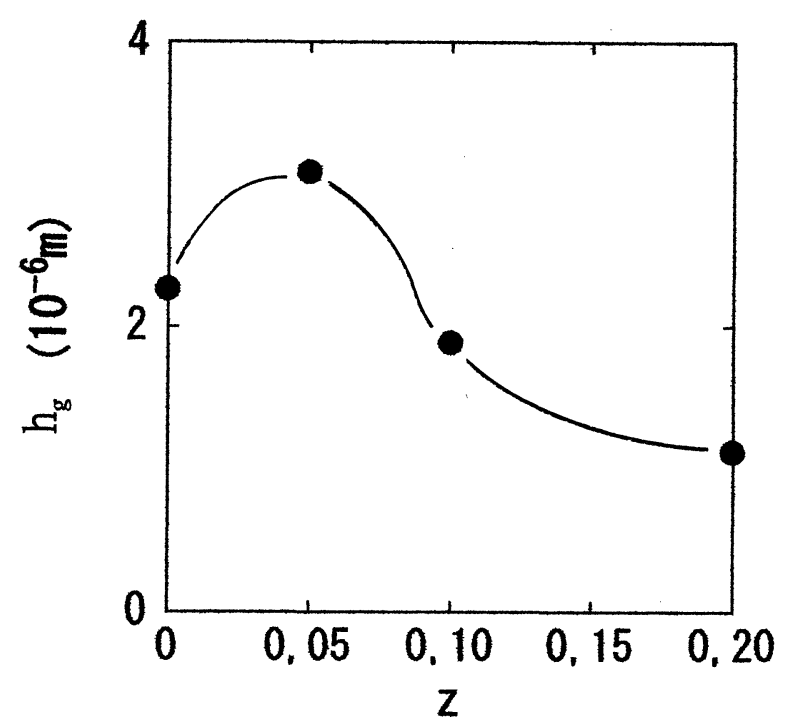

Figure 3. Critical depth $\left(h_{g}\right)$ vs $\mathrm{Mg}$ concentration $(\mathrm{z})$ for $\mathrm{Bi}_{1.6} \mathrm{~Pb}_{0.4-\mathrm{z}} \mathrm{Mg}_{\mathrm{z}} \mathrm{Sr}_{2} \mathrm{Ca}_{2} \mathrm{Cu}_{3} \mathrm{O}_{\mathrm{x}}(0 \leqq \mathrm{z} \leqq 0.2)$

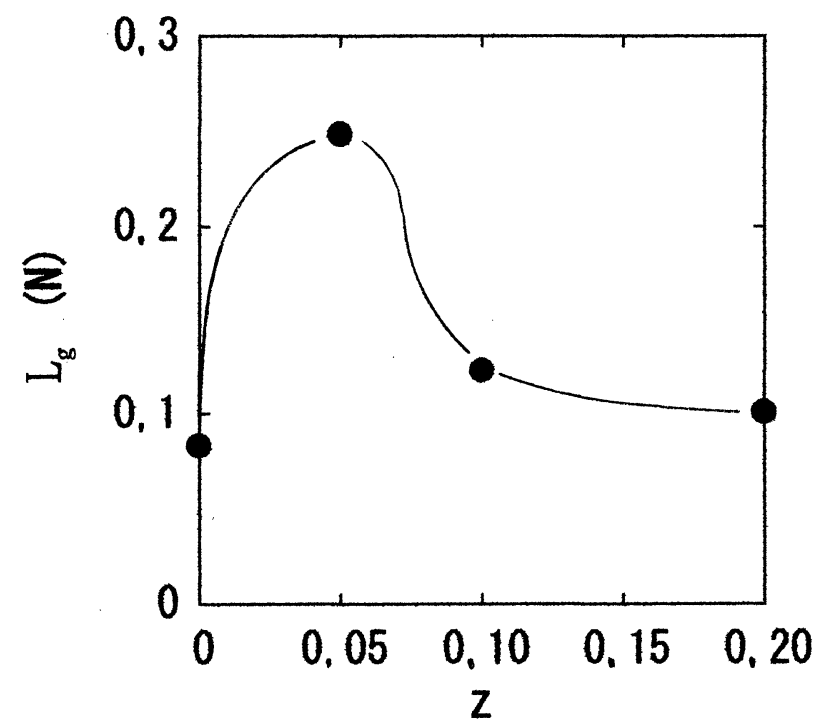

Figure 4. Critical Load $\left(\mathrm{L}_{\mathrm{g}}\right)$ vs Mg concentration $(z)$ for $\mathrm{Bi}_{1.6} \mathrm{~Pb}_{0.4-\mathrm{z}} \mathrm{Hg}_{\mathrm{Z}} \mathrm{Sr}_{2} \mathrm{Ca}_{2} \mathrm{Cu}_{3} \mathrm{O}_{\mathrm{x}}(0 \leqq \mathrm{z} \leqq 0.2)$

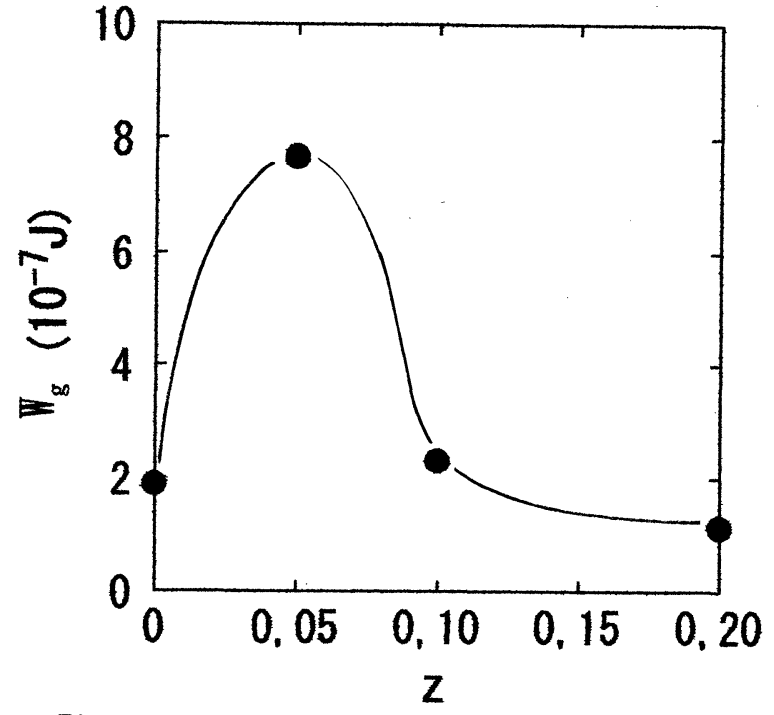

Figure 5. Critical deformation energy $\left(\mathbb{\pi}_{\mathrm{g}}\right)$ vs $\mathrm{Mg}$ concentration $(\mathrm{z})$ for $\mathrm{Bi}_{1.6} \mathrm{~Pb}_{0.4-\mathrm{z}} \mathrm{Hg}_{\mathrm{z}} \mathrm{Sr}_{2} \mathrm{Ca}_{2} \mathrm{Cu}_{3} \mathrm{O}_{\mathrm{x}}(0 \leqq \mathrm{z} \leqq 0.2)$

3 結果之考察

Figure 3 kg 添加量 $(z)$ と。 マイクロクラック発生時の圧子の押し込み深さ $\left(h_{g}\right)$ を示す。ここで、 $h_{\mathrm{g}}$ は $z=0.05$ におい て最大值を示した。Figure 4 に Mg 添加量 $(\mathrm{z})$ とマイクロクラック発生時の荷重 $\left(\mathrm{L}_{\mathrm{g}}\right)$ の関係を示した。 $\mathrm{L}_{\mathrm{g}}$ は $\mathrm{z}=0.05$ の時に最大値を 示した。Figure 5 に Mg 添加量 $(z)$ と マイクロクラック発生時の変形エネルギー $\left(\mathbb{N}_{\mathrm{g}}\right)$ の関係を示す。添加量 $z=0.05$ の時に $\mathbb{W}_{\mathrm{g}}$ は最大值を示しマイクロクラックの発生が抑制 され、脆性が最も改善された。ここで Bi 系酸化物超伝導体の脆さの原因が原子間にお ける圧縮応力場の形成によると仮定した場合、 $\mathrm{Pb}$ よりもイオン半径が小さい Mg を添加することに より、圧縮応力場による歪みが緩和され マイクロクラックの発生が抑制されたと説明する ことができる。一方、添加量を增やすと改善の低 下が見られた。これは $\mathrm{Mg}$ を過剩に添加すること により、逆に引張り応力が生じマイクロクラック が発生しやすくなったためと説明できる。

4 結言

$\mathrm{Bi}$ 系酸化物超伝導体にイオン半径の小さな $\mathrm{Mg}$ を添加することにより脆性の改善が見られた。こ れは、圧縮応力場によって引き起こされていた歪 みが $\mathrm{Mg}$ の添加により緩和されたためと説明でき る。 References

1 Y. Nishi, T. Katagiri, T. Yamano, F. Kanai,

N. Ninomi ya, S. Uchida, K. Oguri, T. Morishita,

T. Endo, and M. Kawakami, Appl. Phys. Lett. 58, 2084 (1991).

2 Y. Nishi, N. Ninomiya, F. Kanai, S. Uchida, and S. Moriya, J. Appl. Phys. 66, 2069 (1989). '94 SAS Intelligent Symposium 